\title{
Pengaruh Strategi Bauran Pemasaran terhadap Minat Berkunjung Kembali di Objek Wisata Ruang Terbuka Hijau Taman Hutan Kota Langsa
}

\author{
Tengku Putri Lindung Bulan ${ }^{1 *}$, M. Lutfi Azmi ${ }^{2)}$ \\ ${ }^{1 *, 2)}$ Program Studi Manajemen, Fakultas Ekonomi, Universitas Samudra \\ e-mail: tengkuputri@unsam.ac.id ${ }^{1 *)}$
}

\begin{abstract}
The purpose of this research was to examine the influence of marketing mix which product, price, promotion, location and physical evidence on revisit intention in Tourist Attractions Ruang Terbuka Hijau Taman Hutan Kota Langsa of students on Fakultas Ekonomi Universitas Samudra. The number of samples in this research as many as 96 respondents. Data analysis method using multiple linear regression analysis. The $t$ test result showed that product, price, location and physical evidence had insignificant influence on revisit intention in Tourist Attractions Ruang Terbuka Hijau Taman Hutan Kota Langsa, while promotion had significant influence on revisit intention. The F test result showed that product, price, location, promotion and physical evidence had significant influence on revisit intention in Tourist Attractions Ruang Terbuka Hijau Taman Hutan Kota Langsa. Based on the results of coefficient of determination can be explained that product, price, promotion, location and physical evidence affect revisit intention in Tourist Attractions Ruang Terbuka Hijau Taman Hutan Kota Langsa by 20,8 \%, while the remaining 79,2\% was influenced by other variables not examined in this research such as people and process.
\end{abstract}

Keyword: Product, Price, Promotion, Location, Physical Evidence, Revisit Intention

\section{PENDAHULUAN}

Sektor kepariwisataan dalam sebuah wilayah mempunyai peranan penting dalam meningkatkan penyerapan tenaga kerja, mendorong pemerataan kesempatan berusaha, mendorong pemerataan pembangunan nasional, dan memberikan kontribusi dalam penerimaan devisa negara yang dihasilkan dari jumlah kunjungan wisatawan mancanegara, serta berperan dalam mengentaskan kemiskinan yang pada akhirnya akan meningkatkan kesejahteraan rakyat. Peranan sektor pariwisata terhadap perekonomian dapat berupa menciptakan atau menambah lapangan dan kesempatan kerja bagi masyarakat sekitar.

Minat diartikan sebagai kehendak, keinginan atau kesukaan (Rossiter, et al., 1997). Minat adalah sesuatu yang pribadi dan berhubungan erat dengan sikap. Minat dan sikap merupakan dasar bagi prasangka, dan minat juga penting dalam mengambil keputusan. Minat dapat menyebabkan seseorang giat melakukan menuju ke sesuatu yang telah menarik minatnya. Minat merupakan sumber motivasi yang mendorong orang untuk melakukan apa yang mereka inginkan bila mereka bebas memilih (Lovelock, 2009).

Minat berkunjung merupakan sesuatu yang berhubungan dengan rencana konsumen untuk mengunjungi tempat tertentu, pada periode tertentu. Perusahaan harus mempelajari keinginan, 
persepsi, preferensi, dan perilaku konsumen sasaran mereka guna menerapkan strategi yang tepat guna menumbuhkan minat berkunjung ke tempat wisata (Siburian, 2013).

Dalam pemasaran biasanya dihadapkan kepada masalah bauran pemasaran. Untuk itu, bauran pemasaran menjadi salah satu faktor penting yang berperan dalam menyukseskan suatu tempat wisata. Bauran pemasaran adalah kumpulan alat pemasaran taktis terkendali yang dipadukan perusahaan untuk menghasilkan respons yang diinginkan di pasar sasaran (Kotler dan Amstrong, 2008). Bauran pemasaran yang dimaksud meliputi 4P (product, price, place promotion) sistem keseluruhan dari kegiatan usaha untuk merencanakan menentukan harga, mempromosikan dan mendistribusikan barang atau jasa yang dapat memuaskan kebutuhan konsumen bauran pemasaran merupakan salah satu konsep kunci dalam teori pemasaran modern. Dalam pemasaran jasa, ada elemen-elemen lain yang bisa dikontrol dan bisa dikombinasikan untuk keperluan komunikasi dengan konsumen jasa elemen tersebut adalah: orang (people), lingkungan fisik (physical evidence) dan proses jasa itu sendiri (process). Dengan demikian 4P yang pada mulanya menjadi bauran pemasaran perlu diperluaskan menjadi 7P jika digunakan dalam pemasaran jasa.

Produk merupakan segala sesuatu yang ditawarkan ke pasar untuk mendapatkan perhatian sehingga dapat dibeli dan dikonsumsi agar dapat memuaskan keinginan atau kebutuhan konsumen. Produk dapat berupa objek secara fisik, jasa, orang, tempat, ide, organisasi, ataupun semua bentukbentuk tadi. Selanjutnya, harga adalah suatu nilai yang digunakan sebagai alat penukar berbagai kombinasi produk ataupun jasa. Dengan demikian, suatu harga haruslah dihubungkan dengan berbagai jenis barang ataupun jasa yang pada akhirnya akan sama dengan sesuatu yaitu produk dan jasa.

Promosi adalah salah satu bauran pemasaran yang berguna untuk menginformasikan, membujuk dan mengingatkan kembali kepada konsumen akan produk ataupun merek perusahaan. Suatu perusahaan pada umumnya melakukan promosi agar konsumen tertarik untuk mengunjungi tempat wisata tersebut. Lokasi merupakan tempat terjadinya berbagai aktivitas pemasaran yang berusaha memperlancar dan mempermudah penyampaian atau penyaluran barang dan jasa dari produsen kepada konsumen. Lokasi tempat wisata yang aman, nyaman, bersih, rapi dan mudah dijangkau merupakan beberapa kriteria yang digemari oleh banyak konsumen.

Orang merupakan semua yang memiliki peranan penting dalam memberikan penyajian jasa atau pelayanan sehingga dapat mempengaruhi sudut pandang dari konsumen. Selanjutnya, proses adalah semua tatacara baik secara aktual, mekanisme maupun aliran aktivitas yang digunakan untuk mencapai jasa. Faktor lain yang mendukung minat berkunjung kembali adalah bukti fisik. Bukti fisik adalah segala sesuatu yang secara nyata dapat mempengaruhi keputusan konsumen untuk membeli dan menggunakan kembali produk dan jasa yang digunakan oleh konsumen. Bukti fisik yang baik seperti fasilitas yang lengkap merupakan salah satu kriteria yang diminati oleh konsumen.

Kota Langsa memiliki sumber-sumber daya yang potensial yang semestinya mampu dioptimalkan untuk kesejahteraan penduduknya, salah satunya pada sektor wisata. Objek wisata yang ada di Kota Langsa salah satunya adalah Ruang Terbuka Hijau Taman Hutan Kota. Hal itu 
dikarenakan sektor ini merupakan sektor andalan yang nantinya diharapkan mampu mendukung perkembangan pembangunan daerah dengan cara usaha ekonomi daerah terpadu/multisektor, serta pemberdayaan dan peningkatan kesejahteraan masyarakat.

Penelitian ini menetapkan bahwa mahasiswa Fakultas Ekonomi Universitas Samudra sebagai objek penelitian. Alasan yang menjadikan pertimbangan menggunakan mahasiswa Fakultas Ekonomi sebagai objek penelitian karena adanya persepsi bahwa mahasiswa Fakultas Ekonomi telah memperoleh pengetahuan dan wawasan yang memadai terkait masalah strategi bauran pemasaran, sehingga memiliki alasan dan argumen yang lebih realistis mengenai variabel yang mempengaruhi minat berkunjung kembali dikalangan mahasiswa. Berdasarkan wawancara yang dilakukan terhadap 20 mahasiswa Fakultas Ekonomi Universitas Samudra yang mengunjungi Ruang Terbuka Hijau Taman Hutan Kota Langsa sebanyak 15 orang menyatakan bahwa dalam bauran pemasaran ditemukan fenomena pada produk yang ditawarkan Ruang Terbuka Hijau Taman Hutan Kota Langsa masih belum dikelola secara maksimal oleh pemerintah dan pengelola tempat wisata sehingga mengurangi daya tarik dari tempat wisata tersebut. Harga yang ditawarkan sedikit mahal dan masih belum sesuai dengan manfaat dari produk yang ditawarkan. Promosi yang dilakukan kurang menarik minat, dan belum adanya website yang memberikan informasi mengenai obyek wisata tersebut secara detail. Lokasinya yang jauh dari pusat kota dan jauh dari jalan lintas, sehingga mempersulit para pengunjung yang ingin mengunjungi obyek wisata tersebut. Bukti fisik yang diberikan oleh Ruang Terbuka Hijau Taman Hutan Kota Langsa masih sangat kurang, bukti fisik yang dimaksud seperti persediaan tempat duduk yang sangat terbatas dan tata letak lingkungan yang ditampilkan tidak tersusun rapi. Sedangkan 5 orang menyatakan bahwa sesuai dengan apa yang didapatkan dengan alasan biaya transportasi yang relatif murah, proses pembelian tiket yang cepat, kemampuan komunikasi pengelola wisata yang sangat baik dan fasilitas lainnya yang tidak dimiliki oleh wisata lainnya yang ada di Langsa. Dengan adanya strategi bauran pemasaran yang diterapkan oleh Ruang Terbuka Hijau Taman Hutan Kota Langsa diharapkan dapat memberikan keuntungan bagi mahasiswa yang mengunjungi sebagai sarana pendidikan dan sebagai sarana rekreasi, dan juga memberikan keuntungan bagi pengelola tempat wisata berupa peningkatan ekonomi yang berguna untuk pengelola tempat wisata dan mensejahterakan masyarakat sekitar.

Adapun tujuan dari penelitian ini adalah sebagai berikut: (1) untuk mengetahui pengaruh produk terhadap minat berkunjung kembali di Objek Wisata Ruang Terbuka Hijau Taman Hutan Kota Langsa, (2) untuk mengetahui pengaruh harga terhadap minat berkunjung kembali di Objek Wisata Ruang Terbuka Hijau Taman Hutan Kota Langsa, (3) untuk mengetahui pengaruh promosi terhadap minat berkunjung kembali di Objek Wisata Ruang Terbuka Hijau Taman Hutan Kota Langsa, (4) untuk mengetahui pengaruh lokasi terhadap minat berkunjung kembali di Objek Wisata Ruang Terbuka Hijau Taman Hutan Kota Langsa, (5) untuk mengetahui pengaruh bukti fisik terhadap minat berkunjung kembali di Objek Wisata Ruang Terbuka Hijau Taman Hutan Kota Langsa, dan (6) untuk mengetahui pengaruh strategi bauran pemasaran (produk, harga, promosi, lokasi dan bukti fisik) secara 
simultan terhadap minat berkunjung kembali di Objek Wisata Ruang Terbuka Hijau Taman Hutan Kota Langsa.

\section{TINJAUAN PUSTAKA}

\section{Bauran Pemasaran}

Sunyoto (2013) menyatakan bahwa bauran pemasaran (marketing mix) sebagai kombinasi dari empat variabel atau kegiatan inti dari sistem pemasaran perusahaan, yaitu produk, harga, kegiatan promosi dan sistem distribusi. Swastha (2009) mengemukakan bahwa bauran pemasaran adalah kombinasi dari empat variabel atau kegiatan yang merupakan inti dari sistem perusahaan.

\section{Bauran Pemasaran Jasa}

Hurriyati (2010) menjelaskan pengertian bauran pemasaran jasa adalah elemen-elemen organisasi perusahaan yang dapat dikontrol oleh perusahaan dalam melakukan komunikasi dengan konsumen dan akan dipakai untuk memuaskan konsumen. Dengan penambahan unsur marketing mix, yaitu orang, proses dan bukti fisik sehingga menjadi tujuh unsur (7P).

\section{Produk}

Menurut Kotler dan Armstrong (2008), produk adalah segala sesuatu yang dapat ditawarkan ke pasar untuk mendapat perhatian, dibeli, digunakan atau dikonsumsi yang dapat memuaskan keinginan atau kebutuhan. Sangadji (2013) menjelaskan bahwa produk adalah segala sesuatu yang dapat ditawarkan kepasar untuk memenuhi kebutuhan dankeinginan konsumen. Produk yang dipasarkan meliputi barang fisik, misalnya mobil makanan, pakaian, perumahan, barang elektronik dan sebagainya.

Menurut Bachtiar (2016), indikator produk adalah sebagai berikut:

1. Fasilitas tujuan wisata, yaitu tersedianya fasilitas seperti kendaraan umum, MCK, dan tempat ibadah.

2. Daya tarik wisata, yaitu tempat wisata yang dituju memiliki pemandangan yang menarik, dan bersih.

\section{Harga}

Menurut Kotler dan Keller (2009), harga adalah salah satu elemen bauran pemasaran yang menghasilkan pendapatan elemen lain menghasilkan biaya. Harga mengkomunikasikan positioning nilai yang dimaksudkan dari produk atau merek perusahaan ke pasar. Produk yang dirancang dan dipasarkan dengan baik dapat dijual dengan harga tinggi dan menghasilkan laba yang besar. Selanjutnya, Assauri (2012) menjelaskan bahwa harga merupakan beban atau nilai bagi konsumen yang didapatkan dengan memperoleh dan menggunakan suatu produk, termasuk biaya keuangan 
dari konsumsi, di samping biaya sosial yang bukan keuangan, seperti dalam bentuk waktu, upaya, psikis, risiko dan prestise atau gengsi sosial.

Indikator harga menurut Stanton (2012), adalah sebagai berikut :

1. Kesesuaian harga dengan kualitas, yaitu kesesuaian harga yang harus dibayar untuk menikmati wisata dengan kualitas produk yang didapatkan (keindahan, kebersihan, sarana dan prasarana).

2. Keterjangkauan harga, yaitu persepsi harga masuk objek wisata.

3. Kesesuaian harga dengan manfaat, yaitu harga yang dikeluarkan untuk menikmati wisata sesuai dengan manfaat rekreasi, dapat menghibur, menghilangkan penat, dan memuaskan.

\section{Promosi}

Tjiptono (2015) menyatakan promosi merupakan elemen bauran pemasaran yang berfokus pada upaya menginformasikan, membujuk, dan mengingatkan kembali kepada konsumen akan merek dan produk perusahaan. Kemudian menurut Hermawan (2012), promosi adalah salah satu komponen prioritas dari kegiatan pemasaran yang memberitahukan kepada konsumen bahwa perusahaan meluncurkan produk baru yang menggoda konsumen untuk melakukan pembelian.

Menurut Bachtiar (2016), untuk mengukur promosi digunakan indikator sebagai berikut:

1. Iklan, yaitu adanya iklan mengenai wisata diberbagai media cetak, internet dan baliho, serta dapat memengaruhi atau menarik wisatawan.

2. Hubungan masyarakat, yaitu adanya kegiatan dari pemerintah yang ditujukan kepada masyarakat sebagai bentuk promosi mengenai pariwisata.

3. Informasi dari mulut ke mulut, yaitu informasi tentang wisata didapatkan oleh pengunjung melalui mulut ke mulut.

\section{Lokasi}

Tjiptono (2015) menjelaskan bahwa lokasi mengacu pada berbagai aktivitas pemasaran yang berusaha memperlancar dan mempermudah penyampaian atau penyaluran barang dan jasa dari produsen kepada konsumen. Sedangkan Setiyaningrum (2015) menyatakan bahwa lokasi adalah sebuah struktur bisnis yang terdiri atas organisasi-organisasi yang saling berkaitan, dimulai dari tempat asal mula produk dibuat sampai penjual terakhir dengan maksud memindahkan produk serta kepemilikan ke pemakai terakhir.

Indikator lokasi menurut Bachtiar (2016), yaitu sebagai berikut :

1. Aksebilitas, misalnya lokasi yang sering dilalui atau mudah dijangkau sarana transportasi.

2. Visibilitas, lokasi atau tempat yang dapat dilihat dengan jelas dari jarak pandang normal.

3. Tempat parkir yang luas, nyaman, dan aman baik untuk kendaraan roda dua maupun roda empat. 


\section{Bukti Fisik}

Hurriyati (2010) menjelaskan bahwa bukti fisik adalah sesuatu hal yang secara nyata mempengaruhi keputusan untuk membeli dan menggunakan produk jasa yang digunakan. Menurut Bachtiar (2016), bukti fisik merupakan suatu hal yang secara turut mempengaruhi keputusan konsumen untuk membeli dan menggunakan produk jasa yang ditawarkan.

Menurut Mulyati dan Afrinata (2018), indikator bukti fisik adalah sebagai berikut:

1. Lingkungan, yaitu lingkungan yang bersih dan nyaman untuk pengunjung.

2. Tata letak yaitu penataan lokasi yang tertata rapi dengan baik dan enak dilihat.

3. Fasilitas tambahan, yaitu terdapat fasilitas tambahan seperti penunjuk arah di kawasan wisata yang pengunjung jelas dan mudah dibaca.

\section{Minat Berkunjung Kembali}

Menurut Umar (2003), minat berkunjung kembali merupakan perilaku yang muncul sebagai respon terhadap objek yang menunjukkan keinginan pelanggan untuk melakukan kunjungan ulang. Nuraeni (2014) menjelaskan bahwa minat berkunjung kembali adalah dorongan seseorang untuk berkunjung kembali ke tujuan yang pernah didatangi. Menurut Putra, dkk (2015) mendefinisikan bahwa minat berkunjung adalah pernyataan keinginan seseorang untuk membeli suatu produk atau jasa.

Menurut Siburian (2013), indikator-indikator dari minat berkunjung kembali antara lain:

1. Keinginan berkunjung di tempat berdasarkan pengalaman pribadi atau sudah pernah berkunjung sebelumnya.

2. Keinginan berkunjung di tempat wisata berdasarkan informasi yang di dapat dari media massa.

3. Keinginan berkunjung di tempat wisata berdasarkan cerita dari keluarga dan sanak saudara.

\section{Hipotesis}

Hipotesis dalam penelitian ini adalah:

1. Produk berpengaruh signifikan terhadap minat berkunjung kembali di Objek Wisata Ruang Terbuka Hijau Taman Hutan Kota Langsa.

2. Harga berpengaruh signifikan terhadap minat berkunjung kembali di Objek Wisata Ruang Terbuka Hijau Taman Hutan Kota Langsa.

3. Promosi berpengaruh signifikan terhadap minat berkunjung kembali di Objek Wisata Ruang Terbuka Hijau Taman Hutan Kota Langsa.

4. Lokasi berpengaruh signifikan terhadap minat berkunjung kembali di Objek Wisata Ruang Terbuka Hijau Taman Hutan Kota Langsa.

5. Bukti fisik berpengaruh signifikan terhadap minat berkunjung kembali di Objek Wisata Ruang Terbuka Hijau Taman Hutan Kota Langsa. 
6. Strategi bauran pemasaran (produk, harga, promosi, lokasi dan bukti fisik) secara simultan berpengaruh signifikan terhadap minat berkunjung kembali di Objek Wisata Ruang Terbuka Hijau Taman Hutan Kota Langsa.

\section{METODE PENELITIAN}

\section{Jenis dan Sumber Data}

Jenis data yang digunakan dalam penelitian ini adalah sebagai berikut:

1. Data kualitatif dalam penelitian ini berupa teori-teori yang mendukung penelitian dan gambaran umum Hutan Lindung Kota Langsa.

2. Data kuantitatif dalam penelitian berupa angka-angka dari tanggapan responden berdasarkan pernyataan pada kuesioner penelitian yang dinilai dengan skala likert (1-5).

Sumber data pada penelitian ini diperoleh dari:

1. Data primer berupa observasi, wawancara, dan memberikan kuesioner kepada responden.

2. Data sekunder dikumpulkan secara studi kepustakaan seperti jurnal, skripsi, buku dan internet yang mendukung penelitian ini.

\section{Populasi dan Sampel}

Populasi dalam penelitian ini adalah mahasiswa Fakultas Ekonomi Universitas Samudra yang berkunjung ke Ruang Terbuka Hijau Taman Hutan Kota Langsa dengan jumlah populasi yang tidak diketahui secara pasti. Untuk menentukan siapa saja untuk menjadi sampel digunakan accidental sampling yaitu teknik pengumpulan sampel dengan berdasarkan kebetulan bertemu peneliti (Sugiyono, 2013) dan sudah mengunjungi Ruang Terbuka Hijau Taman Hutan Kota Langsa minimal sebanyak 2 kali. Karena jumlah populasi tidak bisa dihitung jumlahnya secara pasti, oleh karena itu peneliti menggunakan teknik pengambilan sampel yang ditentukan dengan menggunakan teknik sampling kemudahan (Wibisono dalam Riduwan, 2010) yaitu sebagai berikut:

$$
\begin{aligned}
& \mathrm{n}=\left[\frac{\mathrm{Z} \alpha / 2 \sigma}{\mathrm{e}}\right]^{2} \\
& \mathrm{n}=\left[\frac{(1,96)(0.25)}{0,05}\right]^{2} \\
& \mathrm{n}=96,04 \text { (dibulatkan } 96 \text { responden) }
\end{aligned}
$$

Keterangan:

$\mathrm{n} \quad=$ ukuran sampel

$Z_{\alpha / 2}=$ nilai skor normal $\mathrm{Z}$ untuk tingkat pekercayaan 95\%. Didalam penelitian ini digunakan $\alpha=$ 5\%, sehingga dari tabel distribusi $\mathrm{Z}$ diperoleh $Z_{\alpha / 2}=1,96$

$\sigma \quad=$ standar deviasi $=0,25$

$\mathrm{e} \quad=$ error estimasi (tingkat kesalahan maksimum), dalam hal ini ditetapkan tingkat kesalahan maksimum sebesar 5\%

Jadi jumlah sampel dalam penelitian ini adalah 96 responden. 


\section{Metode Analisis Data}

Metode analisis data dalam penelitian ini menggunakan regresi linier berganda yang bertujuan untuk mengetahui pengaruh bauran pemasaran terhadap minat berkunjung kembali di Objek Wisata Ruang Terbuka Hijau Taman Hutan Kota Langsa. Persamaan regresi linier berganda yang digunakan adalah sebagai berikut:

$$
Y=a+b_{1} X_{1}+b_{2} X_{2}+b_{3} X_{3}+b_{4} X_{4}+b_{5} X_{5}
$$

Keterangan:

$\begin{array}{ll}\mathrm{Y} & =\text { Minat Berkunjung Kembali } \\ \mathrm{a} & =\text { Konstanta } \\ \mathrm{X}_{1} & =\text { Produk } \\ \mathrm{X}_{2} & =\text { Harga } \\ \mathrm{X}_{3} & =\text { Promosi } \\ \mathrm{X}_{4} & =\text { Lokasi } \\ \mathrm{X}_{5} & =\text { Bukti Fisik } \\ \mathrm{b}_{1}, \mathrm{~b}_{2}, \mathrm{~b}_{3}, \mathrm{~b}_{4}, \mathrm{~b}_{5} & =\text { Koefisien Regresi }\end{array}$

\section{HASIL DAN PEMBAHASAN}

\section{Analisis Regresi Linier Berganda}

Untuk mengetahui pengaruh variabel bebas (Produk, Harga, Promosi, Lokasi, Bukti Fisik) terhadap variabel terikat (Minat Berkunjung Kembali) digunakan analisis regresi linier berganda yang diolah melalui program SPSS Versi 23.0, sebagaimana ditunjukkan pada tabel berikut.

Tabel 1. Hasil Analisis Statistik

\begin{tabular}{|c|c|c|c|c|}
\hline Variabel & & B & $\mathrm{t}$ & Sig. $t$ \\
\hline Konstanta & & 0,464 & 0,757 & 0,451 \\
\hline Produk & & 0,097 & 1,116 & 0,268 \\
\hline Harga & & 0,172 & 1,643 & 0,104 \\
\hline Promosi & & 0,265 & 2,431 & 0,017 \\
\hline Lokasi & & 0,152 & 1,653 & 0,102 \\
\hline Bukti Fisik & & 0,208 & 1,851 & 0,067 \\
\hline R Square & $=$ & 0,250 & & \\
\hline Adjusted R Square & $=$ & 0,208 & & \\
\hline $\mathrm{F}$ & $=$ & 5,985 & & \\
\hline Sig. F & $=$ & 0,000 & & \\
\hline
\end{tabular}

Sumber: Data Primer diolah, 2019

Berdasarkan Tabel 1. maka dapat dibuat persamaan sebagai berikut:

$\mathrm{Y}=0,464+0,097 \mathrm{X}_{1}+0,172 \mathrm{X}_{2}+0,265 \mathrm{X}_{3}+0,152 \mathrm{X}_{4}+0,208 \mathrm{X}_{5}$

Persamaan regresi berganda tersebut dapat dijelaskan sebagai berikut:

1. Konstanta sebesar 0,464 menunjukkan nilai minat berkunjung kembali apabila produk, harga, promosi, lokasi dan bukti fisik bernilai nol. 
2. Variabel produk $\left(X_{1}\right)$ memiliki nilai koefisien 0,097 menunjukkan pengaruh yang positif dengan minat berkunjung kembali. Dengan kata lain, apabila produk mengalami peningkatan sebesar satu satuan maka minat berkunjung kembali akan bertambah sebesar 0,097 dengan asumsi bahwa variabel harga, promosi, lokasi dan bukti fisik bernilai tetap.

3. Variabel harga $\left(X_{2}\right)$ memiliki nilai koefisien 0,172 menunjukkan pengaruh yang positif terhadap minat berkunjung kembali. Dengan kata lain, apabila harga mengalami peningkatan sebesar satu satuan maka minat berkunjung kembali akan bertambah sebesar 0,172 dengan asumsi bahwa variabel produk, promosi, lokasi dan bukti fisik bernilai tetap.

4. Variabel promosi $\left(\mathrm{X}_{3}\right)$ memiliki nilai koefisien 0,265 menunjukkan pengaruh yang positif terhadap minat berkunjung kembali. Dengan kata lain, apabila promosi mengalami peningkatan sebesar satu satuan maka minat berkunjung kembali akan bertambah sebesar 0,265 dengan asumsi bahwa variabel produk, harga, lokasi dan bukti fisik bernilai tetap.

5. Variabel lokasi $\left(\mathrm{X}_{4}\right)$ memiliki nilai koefisien 0,152 menunjukkan pengaruh yang positif terhadap minat berkunjung kembali. Dengan kata lain, apabila lokasi mengalami peningkatan sebesar satu satuan maka minat berkunjung kembali akan bertambah sebesar 0,152 dengan asumsi bahwa variabel produk, harga, promosi dan bukti fisik bernilai tetap.

6. Variabel bukti fisik $\left(\mathrm{X}_{5}\right)$ memiliki nilai koefisien 0,208 menunjukkan pengaruh yang positif dengan minat berkunjung kembali. Dengan kata lain, apabila bukti fisik mengalami peningkatan sebesar satu satuan maka minat berkunjung kembali akan turun sebesar 0,208 dengan asumsi bahwa variabel produk, harga, promosi dan lokasi bernilai tetap.

\section{Pembuktian Hipotesis}

\section{Uji t (Uji Signifikansi Parsial)}

Hasil uji t dapat dilihat pada Tabel 1. yaitu sebagai berikut:

1. Hasil nilai signifikansi sebesar 0,268 >0,05 maka Ha ditolak, yang berarti bahwa produk berpengaruh tidak signifikan terhadap minat berkunjung kembali di Objek Wisata Ruang Terbuka Hijau Taman Hutan Kota Langsa sehingga hipotesis pertama dalam penelitian ini ditolak.

2. Hasil nilai signifikansi sebesar 0,104 > 0,05 maka Ha ditolak, yang berarti bahwa harga berpengaruh tidak signifikan terhadap minat berkunjung kembali di Objek Wisata Ruang Terbuka Hijau Taman Hutan Kota Langsa sehingga hipotesis kedua dalam penelitian ini ditolak.

3. Hasil nilai signifikansi sebesar $0,017<0,05$ maka Ha diterima, yang berarti bahwa promosi berpengaruh signifikan terhadap minat berkunjung kembali di Objek Wisata Ruang Terbuka Hijau Taman Hutan Kota Langsa sehingga hipotesis ketiga dalam penelitian ini diterima.

4. Hasil nilai signifikansi sebesar 0,102 > 0,05 maka Ha ditolak, yang berarti bahwa lokasi berpengaruh tidak signifikan terhadap minat berkunjung kembali di Objek Wisata Ruang Terbuka Hijau Taman Hutan Kota Langsa sehingga hipotesis keempat dalam penelitian ini ditolak. 
5. Hasil nilai signifikansi sebesar 0,067 > 0,05 maka Ha diterima, yang berarti bahwa bukti fisik berpengaruh tidak signifikan terhadap minat berkunjung kembali di Objek Wisata Ruang Terbuka Hijau Taman Hutan Kota Langsa sehingga hipotesis kelima dalam penelitian ini ditolak.

\section{Uji F (Uji Signifikansi Simultan)}

Dari Tabel 1. dapat diketahui nilai F sig. sebesar 0,000. Oleh karena nilai F sig. 0,000 <0,05, maka Ha diterima. Artinya produk, harga, promosi, lokasi dan bukti fisik secara simultan berpengaruh signifikan terhadap minat berkunjung kembali di Objek Wisata Ruang Terbuka Hijau Taman Hutan Kota Langsa sehingga hipotesis keenam dalam penelitian ini diterima.

\section{Koefisien Determinasi}

Berdasarkan Tabel 1. terlihat bahwa nilai Adjusted R square sebesar 20,8\%. Hal ini berarti kontribusi variabel produk, harga, promosi, lokasi dan bukti fisik terhadap minat berkunjung kembali di Objek Wisata Ruang Terbuka Hijau Taman Hutan Kota Langsa sebesar 20,8\%, sementara sisanya $79,2 \%$ dipengaruhi oleh variabel lain yang tidak diteliti seperti variabel orang dan proses.

\section{Pembahasan}

\section{Pengaruh Produk terhadap Minat Berkunjung Kembali}

Produk berpengaruh tidak signifikan terhadap minat berkunjung kembali di Objek Wisata Ruang Terbuka Hijau Taman Hutan Kota Langsa. Hal ini dikarenakan produk wisata yang disediakan oleh pemerintah dan pihak pengelola tidak memiliki daya tarik dan tidak memberikan kepuasan sehingga mempengaruhi minat mahasiswa untuk berkunjung kembali ke Ruang Terbuka Hijau Taman Hutan Kota Langsa. Hasil ini berbeda dengan penelitian yang dilakukan oleh Bachtiar (2016), Siburian (2013), dan Mulyati dan Afrinata (2018) yang menyatakan bahwa produk berpengaruh signifikan terhadap minat berkunjung kembali.

\section{Pengaruh Harga terhadap Minat Berkunjung Kembali}

Harga berpengaruh tidak signifikan terhadap minat berkunjung kembali di Objek Wisata Ruang Terbuka Hijau Taman Hutan Kota Langsa. Hal ini dikarenakan harga tiket masuk yang masih relatif mahal dan belum sesuai manfaatnya dengan apa yang didapatkan oleh mahasiswa yang berkunjung. Ini berarti bahwa seberapa besar harga yang ditetapkan oleh pemerintah ataupun pihak pengelola, asalkan produk wisata yang disediakan sesuai harapan dan mempunyai manfaat yang dirasakan oleh mahasiwa maka harga bukanlah faktor penentu bagi mahasiswa untuk berkunjung kembali ke Ruang Terbuka Hijau Taman Hutan Kota Langsa. Hasil ini berbeda dengan penelitian yang dilakukan oleh Bachtiar (2016) dan Siburian (2013) yang menyatakan harga berpengaruh signifikan terhadap minat berkunjung kembali. 


\section{Pengaruh Promosi terhadap Minat Berkunjung Kembali}

Promosi berpengaruh signifikan terhadap minat berkunjung kembali di Objek Wisata Ruang Terbuka Hijau Taman Hutan Kota Langsa. Ini berarti bahwa promosi pada Objek Wisata Ruang Terbuka Hijau Taman Hutan Kota Langsa akan mempengaruhi minat berkunjung kembali mahasiswa. Meskipun belum ada Website yang memberikan informasi mengenai objek wisata secara detail tetapi dengan informasi Word of Mouth melalui teman mengenai objek wisata Ruang Terbuka Hijau Taman Hutan Kota Langsa maka akan mempengaruhi minat berkunjung kembali.

Hasil penelitian ini didukung oleh pendapat Hermawan (2012), yang menjelaskan promosi adalah salah satu komponen prioritas dari kegiatan pemasaran yang memberitahukan kepada konsumen bahwa perusahaan meluncurkan produk baru yang menggoda konsumen untuk melakukan pembelian. Berdasarkan definisi ini maka promosi merupakan alat komponen informasi yang tepat yang dapat berpengaruh terhadap minat berkunjung kembali. Konsumen akan mengetahui suatu produk ataupun jasa melalui promosi yang dilakukan oleh pemerintah atau pihak pengelola objek wisata sehingga dapat mempengaruhi minat berkunjung kembali. Hasil ini sesuai dengan penelitian yang dilakukan oleh Bachtiar (2016) dan Siburian (2013) yang menyatakan promosi berpengaruh signifikan terhadap minat berkunjung kembali.

\section{Pengaruh Lokasi terhadap Minat Berkunjung Kembali}

Lokasi berpengaruh tidak signifikan terhadap minat berkunjung kembali di Objek Wisata Ruang Terbuka Hijau Taman Hutan Kota Langsa. Hal ini dikarenakan lokasinya yang berada di pinggiran kota dan aksesnya yang terlalu sempit sehingga mempengaruhi minat berkunjung kembali. Hasil penelitian ini berbeda dengan penelitian yang dilakukan oleh Bachtiar (2016), dan Mulyati dan Afrinata (2018) yang menyatakan lokasi berpengaruh signifikan terhadap minat berkunjung kembali.

\section{Pengaruh Bukti Fisik terhadap Minat Berkunjung Kembali}

Bukti fisik berpengaruh tidak signifikan terhadap minat berkunjung kembali di Objek Wisata Ruang Terbuka Hijau Taman Hutan Kota Langsa. Hal ini dikarenakan bukti fisik yang disediakan oleh pemerintah atau pihak pengelola berupa lingkungan yang kurang bersih dan tata ruang objek wisata yang kurang sesuai sehingga mengganggu kenyamanan mahasiswa yang datang berkunjung. Hasil ini berbeda dengan penelitian yang dilakukan oleh Bachtiar (2016), dan Mulyati dan Afrinata (2018) yang menyatakan bukti fisik berpengaruh signifikan terhadap minat berkunjung kembali.

\section{Pengaruh Produk, Harga, Promosi, Lokasi, dan Bukti Fisik terhadap Minat Berkunjung}

\section{Kembali Secara Simultan}

Produk, harga, promosi, lokasi dan bukti fisik secara simultan berpengaruh signifikan terhadap minat berkunjung kembali di Objek Wisata Ruang Terbuka Hijau Taman Hutan Kota Langsa. Hasil ini sesuai dengan penelitian yang dilakukan oleh Bachtiar (2016), dan Mulyati dan Afrinata (2018) yang 
mengatakan bahwa bauran pemasaran (produk, harga, promosi, lokasi dan bukti fisik) secara simultan berpengaruh signifikan terhadap minat berkunjung kembali.

Hurriyati (2010) menyatakan bahwa bauran pemasaran jasa merupakan elemen-elemen organisasi perusahaan yang dapat dikontrol oleh perusahaan dalam melakukan komunikasi dengan konsumen dan akan dipakai untuk memuaskan konsumen. Dengan penambahan unsur marketing mix, yaitu orang, proses dan bukti fisik sehingga menjadi tujuh unsur (7P). Hal ini membuktikan bahwa apabila strategi bauran pemasaran diterapkan dengan tepat maka akan mempengaruhi minat berkunjung kembali.

Menurut Umar (2003), minat berkunjung kembali merupakan perilaku yang muncul sebagai respon terhadap objek yang menunjukkan keinginan pelanggan untuk melakukan kunjungan ulang. Hal ini berarti bahwa pengalaman yang muncul dari sikap positif konsumen untuk mendapatkan apa yang mereka butuhkan dan inginkan sehingga konsumen akan melakukan pembelian ulang. Jadi dapat disimpulkan bahwa penerapan strategi bauran pemasaran yang tepat pada Objek Wisata Ruang Terbuka Hijau Taman Hutan Kota Langsa yaitu produk, harga, promosi, lokasi dan bukti fisik maka akan meningkatkan minat mahasiswa untuk berkunjung kembali.

\section{KESIMPULAN DAN SARAN}

Berdasarkan hasil penelitian dan pembahasan yang dilakukan maka dapat disimpulkan sebagai berikut: (1) hasil persamaan regresi linier berganda menunjukkan bahwa model tersebut menggambarkan produk, harga, promosi, lokasi dan bukti fisik berpengaruh positif terhadap minat berkunjung kembali di Objek Wisata Ruang Terbuka Hijau Taman Hutan Kota Langsa, (2) hasil uji t diketahui bahwa produk, harga, lokasi dan bukti fisik berpengaruh tidak signifikan terhadap minat berkunjung kembali di Objek Wisata Ruang Terbuka Hijau Taman Hutan Kota Langsa, sedangkan untuk variabel promosi berpengaruh signifikan terhadap minat berkunjung kembali di Objek Wisata Ruang Terbuka Hijau Taman Hutan Kota Langsa, (3) Hasil uji F diketahui bahwa produk, harga, promosi, lokasi dan bukti fisik secara simultan berpengaruh signifikan terhadap minat berkunjung kembali di Objek Wisata Ruang Terbuka Hijau Taman Hutan Kota Langsa, dan (4) hasil koefisien determinasi dapat dijelaskan bahwa kontribusi variabel produk, harga, promosi, lokasi dan bukti fisik mempengaruhi minat berkunjung kembali di Objek Wisata Ruang Terbuka Hijau Taman Hutan Kota Langsa sebesar $20,8 \%$, sisanya sebesar $79,2 \%$ dipengaruhi oleh variabel lain yang tidak diteliti dalam penelitian ini seperti variabel orang dan proses.

Berdasarkan hasil penelitian dan pembahasan dapat disarankan yaitu: (1) untuk variabel produk, sebaiknya pemerintah dan pengelola tempat wisata harus lebih meningkatkan kembali dengan cara menambah produk seperti menambah flora berupa varietas bunga dan tanaman yang dapat memberikan pengaruh dan menjadi daya tarik bagi wisatawan, menambah spesies fauna seperti burung hantu, burung merak dan spesies mamalia lainnya serta menambah area permainan seperti ayunan, perosotan, jungkat-jungkit dan juga memperbaiki fasilitas flying fox agar lebih menarik minat 
wisatawan untuk berkunjung kembali yang nantinya akan membawa manfaat, (2) untuk variabel harga, sebaiknya pihak pengelola harus menyesuaikan harga tiket masuk dengan produk yang ditawarkan, sebab harga yang sesuai dengan apa yang ditawarkan dapat mempengaruhi minat berkunjung kembali wisatawan, (3) untuk variabel promosi, sebaiknya pemerintah, pengelola dan masyarakat sekitar melakukan promosi yang lebih gencar lagi diberbagai media termasuk pemanfaatan media sosial, seperti facebook, instagram dan sosial media lainnya sehingga memudahkan pengunjung untuk memperoleh informasi, (4) untuk variabel lokasi, sebaiknya pemerintah dan pengelola tempat wisata membenahi akses jalan yang layak dan nyaman, juga melakukan penambahan dan perbaikan beberapa fasilitas seperti jalan masuk dan jalan dalam kawasan objek wisata guna menambah minat pengunjung untuk berkunjung kembali, (5) untuk variabel bukti fisik, sebaiknya pemerintah dan pengelola tempat wisata meningkatkan lagi bukti fisik yang ada, mengingat bahwa pengunjung memiliki kebutuhan lain seperti sarana prasarana yang dibutuhkan pengunjung misalnya: tempat ibadah, toilet, dan bangku/tempat duduk, dan (6) bagi peneliti selanjutnya dapat mengembangkan penelitian ini dengan menambahkan variabel-variabel lain yang dapat mempengaruhi minat berkunjung kembali seperti variabel orang dan proses.

\section{REFERENSI}

Assauri, Sofjan. 2012. Manajemen Pemasaran. Jakarta: Raja Grafindo Persada.

Bachtiar, M. Latief. 2016. Pengaruh Strategi Bauran Pemasaran terhadap Minat Berkunjung Kembali di Objek Wisata Pantai Kabupaten Gunung Kidul. Jurnal Manajemen Bisnis Indonesia. Vol. 5 No. 1. Hal: 40-49.

Hermawan, Agus. 2012. Komunikasi Pemasaran. Jakarta: Erlangga.

Hurriyati, Ratih. 2010. Bauran Pemasaran dan Loyalitas Konsumen. Bandung: Alfabetha.

Kotler, Philip dan Gary Armstrong. 2008. Prinsip-Prinsip Pemasaran. Jakarta: Erlangga.

Kotler, Philip dan Kevin Lane Keller. 2009. Manajemen Pemasaran. Jakarta: Erlangga.

Lovelock. 2009. Manajemen Pemasaran Jasa Jilid 1. Jakarta: PT. Indeks.

Mulyati, Yofina dan Miko Afrinata. 2018. Analisis Pengaruh Strategi Bauran Pemasaran terhadap Minat Berkunjung Kembali pada Destinasi Wisata Pantai Carocok Painan Kabupaten Pesisir Selatan. Jurnal Akuntansi, Ekonomi dan Manajemen Bisnis. Vol. 6 No. 2. Hal: 191-200.

Nuraeni, Bellinda Sofia. 2014. Analisis Faktor-Faktor yang Mempengaruhi Kunjung Ulang Wisatawan Museum Ranggawarsita Semarang. Jurnal Bisnis Strategi. Vol. 5 No. 1. Hal: 1-20.

Putra, Gagah Bimo Setya, dkk. 2015. Pengaruh Citra Perusahaan terhadap Minat Berkunjung dan Keputusan Berkunjung Taman Rekreasi PT. Selecta Kota Batu Malang. Jurnal Administrasi Bisnis. Vol. 26 No. 2. Hal: 1-8.

Riduwan. 2010. Metode dan Teknik Menyusun Tesis. Bandung: Alfabeta.

Rossiter, John R. and Larry Percy. 1997. Advertising and Promotion Management. New York: McGraw-Hill.

Sangadji, E. M dan Sopiah. 2013. Consumer Behavior: Perilaku Konsumen dan Strategi Pemasaran Jilid 2. Jakarta: Erlangga.

Setiyaningrum, Ari. 2015. Prinsip-Prinsip Pemasaran. Yogyakarta: Andi.

Siburian, Kezia Cempaka. 2013. Pengaruh Produk, Harga, Lokasi dan Promosi terhadap Minat Berkunjung Kembali ke Tempat Wisata Draco Waterpark Hermes Medan. Skripsi. Program Studi Strata 1 Manajemen Departemen Manajemen Fakultas Ekonomi. Universitas Sumatera Utara. Medan.

Sugiyono. 2013. Metode Penelitian Manajemen. Bandung: Alfabeta.

Sunyoto, Danang. 2013. Perilaku Konsumen. Yogyakarta: CAPS.

Swastha, Basu. 2009. Azas-Azas Marketing. Yogyakarta: Liberty. 